\title{
What can we learn from old ditrital zircon? A comparison between zircon from Acasta and Jack Hills
}

\section{J.R. REIMINK ${ }^{1}$, J.H.F.L.DAVIES ${ }^{2}$, ANN M. BAUER ${ }^{3}$, THOMAS CHACKO ${ }^{4}$}

${ }^{1}$ Department of Geosciences, The Pennsylvania State University, PA, USA, jreimink@psu.edu

${ }^{2}$ Département des Sciences de la Terre et de l'Atmosphère, Université du Québec à Montréal, Montréal, QC, H2X3Y7, Canada

${ }^{3}$ Department of Geoscience, University of WisconsinMadison, Madison, WI, 53706, United States of America ${ }^{4}$ Department of Earth and Atmospheric Sciences, University of Alberta, Edmonton, AB, T6G 2E3, Canada

The earliest evidence for terrestrial contienntal crust on Earth comes from the Jack Hills zircon population, some of which crystalized $>4.3 \mathrm{Ga}$. The isotopic and elemental compositions of these rare detrital grains have been instrumental in developing our understanding of the early crust on Earth. However, there is no general consensus on the rock compositions parental to these valuable zircon grains. Here we compare the chemistry of the Jack Hills zircons to a new zircon dataset from the 4.0-2.95 Ga Acasta Gneiss complex in the western margin of the Slave craton in Northern Canada.

The AGC has previously been studied in detail, with a wide variety of existing whole-rock and zircon datasets. By comparing whole-rock and zircon analyses, we show that zircon REE patterns are, at best, tenuous indicators of primary magmatic REE patterns, particularly for ancient zircon grains. However, we document a systematic co-variation in wholerock $\mathrm{La} / \mathrm{Yb}$ and zircon $\mathrm{U} / \mathrm{Yb}$, which shows potential for tracing a residual garnet signature in the magma source rocks and in turn providing constraints on the depth of melting.

We show that the ACG zircon crystals have very similar Ti concentrations to the Jack Hills zircons, potentially indicating similar crystallization temperatures. These low Ti concentrations are distinct from zircons that form in mafic settings, but indistiguishable from many other felsic rocks. $\mathrm{We}$ also compare compilations of $\mathrm{Hf}$ and $\mathrm{O}$ isotopic data from the Jack Hills and AGC zircons, and show that they are nearly indistiguishable, with age being the only major difference. We therefore conclude that the geological setting for the Jack Hills zircons may have been analogous to that of the AGC. 